\author{
Terbit Setya Pambudi \\ Program Studi Desain Produk \\ Universitas Telkom \\ terbitsetyapambudi@tcis.telkomuniversity.ac.id
}

\title{
PERAN MEDIA DALAM MENGINFORMASIKAN WACANA GREEN DESIGN KEPADA MASYARAKAT
}

\begin{abstract}
Abstrak: Global warming, kerusakan ekologi hingga perubahan iklim yang ekstrim adalah isu lingkungan yang saat ini menajdi topik pembahasan masyarakat luas. Isu lingkungan ini juga menarik perhatian pada dunia desain, green design muncul sebagai jawaban akan isu lingkungan tersebut. Wacana green design yang mengarah pada pola pikir dan tindakan yang menghargai dan ramah lingkungan yang berkelanjutan. Untuk memberikan informasi dan pengetahuan mengenai wacana green design kepada masyarakat perlu sebuah komunikasi melalui media. Media sebagai bentuk komunikasi massa berfungsi sebagai pemberi informasi, pencetus opini publik hingga pembentuk budaya massa. Dalam peranya pada wacana green design, media berfungsi sebagai pemberi informasi, mengenalkan wawasan baru, mempersuasi pola pikir dan tindakan masyarakat ke arah wacana green design yang menghargai dan ramah terhadap lingkungan secara berkelanjutan. Penelitian ini menggunakan metode kulitatif dengan melakukan kajian terhadap fenomena yang ada di masyarakat berdasar pada kajian literatur. Fokus penelitian adalah mengenai peran media dalam memberikan informasi kepada masayarakat tentang wacana green design. Dalam makalah ini didapatkan kesimpulan peran media pada wacana green design. Media sebagai sarana kampanye dengan tujuan untuk meningkatakan kesadaran, memberi informasi dan merubah pola pikir ke arah green design. Peran media sebagai sarana edukasi green design dengan tujuan memberi pengetahuan baru kemudian mempersuasi pola pikir dan tindakan masyarakat menuju wacana green design. Selanjutnya media digunakan produsen untuk membujuk konsumen untuk menyakini dan kemudian membeli dan menggunakan produk green design.
\end{abstract}

Kata kunci: isu lingkungan, green design, peran media, kampanye, edukasi, promosi

Abstract: Global warming, ecological damage, extreme climate change, are environmental issues which are currently topics of wide public discussion. Environmental issues also drew attention to the world of design, green design emerged as an answer to environmental issues. Discourse green design that leads to thinking and action that respects and environmentally sustainable. To provide information and knowledge about green design to the public discourse needs to be a communication through the media. The media as a form of mass communication serves as a conduit of information, the originator of forming public opinion and mass culture. In his role in the discourse of green design, the media serves as a conduit of information, introduce new insights, to persuade the public mindset and actions towards the discourse of green design that respects and friendly to the environment in a sustainable manner. This study uses a qualitative method to conduct studies on the phenomenon exists in the community based on a review of the literature. The focus of research is on the role of the media in providing information to the community about green design discourse. In this paper, it was concluded the media's role in the discourse of green design. Media as a means campaign with the aim to increase the awareness, inform and change mindsets towards green design. The role of the media as a means of education green design with the aim of giving new knowledge and then persuade the public mindset and actions towards green design discourse. Furthermore, media enables producers to persuade consumers to believe and then buy and use a green product design

Keywords: environmental issues, green design, the role of media, campaigns, education, promotion 


\section{Latar Belakang}

Isu kerusakan lingkungan yang banyak menjadi fokus belakangan ini juga berpengaruh pada dunia desain. Green design lahir sebagai jawaban akan isu kerusakan lingkungan yang terjadi. Wacana dari green design adalah merubah pola pikir dan tindakan masyarakat menuju lebih menghargai dan ramah lingkungan secara berkelanjutan. Untuk menyampaikan wacana ini kemasyarakat luas diperlukan sebuah komunikasi sebagai sarana penyampainya. Pola komunikasi yang perlu dipakai adalah pola komunikasi massa. Bentuk dari komunikasi massa salah satunya adalah media, disini peran media diperlukan. Bagaimana peran dan fungsi media pada wacana green design dalam menginformasikan dan memberi pengetahuan baru kepada masyarakat.

Green design muncul sebagai salah satu jawaban dalam menanggapi isu kerusakan lingkungan yang sedang terjadi. Peran media sebagai alat komunikasi diperlukan untuk memberikan informasi mengenai wacana green design. Media memegang peran penting dalam menyampaikan informasi mengenai wacana tersebut, apalagi dewasa ini media informasi sudah pada era media komunikasi interaktif. Dimana media sudah sangat mudah dipunyai dan digunakan hampir semua lapisan masyarakat.

\section{Kajian Literatur}

\subsection{Perkembangan media}

Media dewasa ini berkembang begitu pesat, sejalan lurus dengan semakin tinggi dan kompleknya kebutuhan manusia akan komunikasi dan interaksi sebagai mahluk sosial. Perkembangan media diawali dari jaman prasejarah yang menggunakan bahasa verbal sebagai sebuah media komunikasi dan terus berkembang menjadi simbol, bahasa hingga kini memasuki dunia dengan teknologi yang tinggi sehingga menciptakan media - media baru dalam upaya pemenuhan akan sarana komunikasi yang lebih memadai. Menurut Roger Fidler proses perkembangan media adalah sebuah mediamorfosis, yang dalam bukunya mengkategorikan proses perkembangan media itu menjadi tiga, yaitu koevolusi yang merupakan kelindanan dengan susunan sistem komunikasi, konvergensi dimana muncul gagasan bahwa berbagai macam teknologi dan bentuk media hadir secara bersamaan menbentuk masa depan media yang baru dan beragam, kompleksitas ( chaos ) yaitu gagasangagasan baru tak terduga akibat kejadian - kejadian yang saling bervariasi bertransformasi dan menghidupkan sistem - sistem.

Rogers (1986) mengemukakan bahwa ada 4 era komunikasi yang terbentuk dalam masyarakat yaitu, era tulis, era cetak, era telokmunikasi dan era komunikasi interaktif. Era tulis merupakan pertanda permulaan sebuah peradaban sebuah bangsa. Dari kemampuan menulis memberikan manfaat terpeliharanya struktur sosial sebuah wilayah atau masyarakat. Penemuan relief, ukiran, tanda dan grafik dalam berbagai media tulis merupakan bukti temuan budaya tulis dar berbagai bangsa di dunia. Era cetak meruapkan awal baru penerapan teknologi dalam mencetak dan mengabadikan tulisan dengan jumlah yang lebih besar. 
Penemuan mesin cetak Gutenberg merupakan terobosan besar yang kemudia melahirkan media berupa surat kabar. Dan sampai saat ini media cetak masih mampu bertahan sebagai salah satu teknologi media yang umum dikenal dan digunakan. Era telekomunikasi adalah dimana manusia untuk saling berhubungan satau sama lain tanpa terhalang oleh jarak, kecepatan dan waktu. Media yang digunakan sering disebut sebagai media elektronik, penemuan telegrap, telepon hingga televeli adalah bukti perkembangan era telekomunikasi. Era komunikasi interaktif ditandai dengan munculnya berbagai teknologi informasi dengan bergabungnya telepon, radio komputer dan televisi menjadi sebuah media yang disebut internet. Perkembangan teknologi internet yang begitu cepat saat ini sudah dapat dijangkau oleh sebagian besar masyarakat dunia, menggantikan media komunikasi ynag sudah ada sebeleumnya. Kecepatan, kepraktisan dan kecanggihan teknologi merupakan keunggulan dari media internet yang membuat media tersebut menjadi populer saat ini. Seiring berkembangnya kebutuhan dan keinginan manusia berpengaruh juga terhadap pola perkembangan media sebagai pemenuhan kebutuhan dan keinginan manusia.

\subsection{Isu lingkungan}

Pemanasan global akibat polusi udara dari pembakaran bahan bakar oleh industri, kendraan bermotor hingga di skala rumah tangga, penebangan kayu secara liar tanpa mepedulikan penggatian pohon dan hutan tempat penebangan mengakibatkan banjir, tanah longsor hingga kepunahan hewan langka tertentu,semakin besarnya jumlah sampah yang tidak terkelola dengan baik hingga perubahan iklim yang ekstrem merupakan beberapa topik utama isu lingkungan. Dimana setiap isu lingkungan saling terkait dan menimbulkan masalah baru pada lingkungan. Pada dasar jika ditelusuri kebelakang maka semua isus kerusakan lingkungan tersebut merupakan hasil dari kegiatan manusia dalam memenuhi kebutuhan hidupnya. Isu tersebut mulai kerap dibahas ketika kemajuan teknologi industri dalam memenuhi kebutuhan konsumerisme semakin lama membawa dampak buruk yang nyata bagi lingkungan.

Saat ini isu tersebut merupakan masalah serius yang berpengaruh bukan hanya pada ekologi lingkungan namun juga terhadap sektor ekonomi dunia dan kondisi sosial masayarakat. Bukan hanya sebagai akibat dari kemajuan industri namun saat ini isu lingkungan menjadi bagian penting perkembangan industri di masa depan dan menentukan bagaimana keadaan sosial, ekonomi serta lingkungan secara global di masa depan. Maka muncul sebuah wacana baru yang direncanakan mampu menjawab atau setidaknya untuk mengurangi dampak negatif isu kerusakan lingkungan, wacana tersebut berupa sebuah konsep green design. berisi tentang konsep dan bagaimana kita bertindak secara benar dan baik yang selaras dengan alam. 


\subsection{Green design}

Sebuah wacana baru menjawab isu lingkungan yang marak belakangan ini. Ada beberapa defini mengenai green design.Didalam kamus Design Oxford, green design adalah Essentially, green design embraces ecological considerations, sustainability, recycling, conservation of resources, and cleaner, quieter, and safer domestic environments. Green design adalah filosofi mengenai bagaimana menciptakan desain produk, membangun lingkungan dan memberikan jasa pelayanan yang berdasar dan patuh pada prinsip - prinsip berkelanjutan baik dari segi ekonomi, sosial dan ekologi. Green design adalah proses dan pengembangan sebuah produk yang lebih ramah lingkungan. Penerapanya melibatkan kerangka tertentu untuk mempertimbangkan masalah lingkungan, penerapan analisis yang relevan dan metode yang sintesis, dan tantangan pada proses manufaktur dan prduksi tradisional (Hendrickson, et al). Secara umum dan sederhana pengartian green design disini adalah desain yang ramah lingkungan.

Tujuan utama dari wacana green design bagaimana proses pengolahan limbah dan pemilihan material yang ramah linkungan didasari pada prinsip ekonomi, kesadaran sosial dan menjaga ekologi linkungan ( Conggres of United States Office of Technology Assessment, 1992 ). McLennan (2004) mengatakan bahwa penerapan green design adalah untuk menghilangkan atau mengurangi dampak negatif pada lingkungan yang diakibatkan oleh tindakan dan prilaku manusia. Menciptakan desain dan industri yang berkelanjutan, mengurangi atau tidak menggunakan sumber daya alam yang tidak terbarukan secara berlebihan, mengurangi semaksimal mungkin dampaknya terhadap lingkungan, dan selaras dengan alam. Selain itu green design harus menciptakan inovasi - inovasi yang dapat mengubah prilaku manusia menjadi lebih baik. Menciptakan keseimbangan ekonomi, sosial dan ekologi lingkungan sehingga produsen dan konsumen sadar dan ikut serta untuk menjaga dan menghargai lingkungan sekitar (http://engagebydesign.org/)

Tujuan dari wacana green design bukan hanya mengenai proses dan hasil desain saja, namun juga bagaimana cara berpikir, pola bertindak secara berkesinambungan didasari pada prinsip ekonomi, kesadaran sosial dan menjaga ekologi linkungan. Namun pada kenyataanya wacana tentang green design belum terlaksana sepenuhnya, sebagian besar produsen dan konsumen masih belum mengerti secara utuh. Banyak produsen hanya memujudkan wacana green design itu pada hasil akhirnya saja, dan green design digunakan sebagai salah satu strategi pemasaran.

\section{Metoda Penelitian}

Metode penelitian yang digunakan adalah metode penelitian kualitatif. Pendekatan analisa deskriptif pada isu dan fenomena yang terjadi dengan berdasar pada studi literatur mengenai media, komunikasi dan konsep green design. Analisa yang dilakukan untuk mengetahui apa saja peran media dalam memberikan informasi kepada masyarakat awam mengenai wacana green design sebagai salah satu jawaban atas isu kerusakan lingkungan 
yang sedang terjadi. Selajutnya analisa digunakan untuk menemukan bagaiaman peran media dalam hal ini bentuk dan fungsi media pada wacana green design. yang terahir adalah analisa mengenai sejau manakah peran media dan hasilnya dalam memberikan informasi mengenai wacan green design pada masyarakat luas. Dari hasil analisa diharapkan mampu memberikan jawaban secara deskriptif tentang peran media pada wacana green design yang kemudian dimanfaatkan sebagai referensi atau masukan dalam mengembangkan peran media lebih lanjut dalam mendukung gerakan green design pada masyarakat luas.

\section{Hasil/Temuan}

\subsection{Peran media pada wacana Green design}

Untuk menyampaikan wacana ini ke masyarakat luas diperlukan sebuah komunikasi sebagai sarana penyampainya. Pola komunikasi yang perlu dipakai adalah pola komunikasi massa. Menurut Mulyana ( 2008:83 ) :

"Komunikasi massa ( mass communication) adalah komunikasi yang menggunakan media massa, baik cetak ( surat kabar, majalah ) atau elektronik ( radio, televisi ), berbiaya relatif mahal, yang dikelola oleh suatu lembaga atau orang yang di lembagakan, yang ditujukan kepada sejumlaha besar orang yang tersebar di banyak tempat, anonim, dan hetorogen. Pesan - pesannya bersifat umum, disampaikan secara cepat dan selintas ( khusunya media elektronik)".

Dalam teori komunikasi massa, konsep masyarakat massa mendapat relasi dan pengaruh kuat dari produk budaya massa yang ada, pada ahirnya akan mempengaruhi bagaimana proses komunikasi dalam konteks masyarakat massa membentuk dan dibentuk oleh budaya massa tersebut. Media massa berperan penting untuk membentuk keragaman budaya yang dihasilkan sebagai salah satu akibat pengaruh media terhadap sistem nilai, pikir dan tindakan manusia. Peran media disadari ataupun tidak sampai saat ini masih dan akan terus menjadi penentu atau bahkan pencetus dari sebuah opini publik yang ada di masyarakat.

Begitu pula peran media pada wacana green design yang saat ini menjadi topik yang hangat dan banyak menjadi fokus yang dibahas oleh masyarakat desain. Disini peran media begitu penting dalam menyampaikan wacana green design secara jelas kepada masyarakat. Tanpa peran media wacana green design sebagai jawaban solusi masalah isu lingkungan akan hanya menjadi wacana saja tanpa ada implementasi yang nyata dari masyarakat. Melalui media masyarakat akan diarahkan pola pikir dan tindakanya menuju pola pikir green design yang menghargai lingkungan sebagai budaya baru masyarakat. Bagaimana masyarakat mendapat berita, wawasan dan pengetahuan tentang green design secara jelas melalui beberapa bentuk media yang ada sekarang. Disinilah bagaimana peran media sangat penting dalam masalah ini. Media mempunyai tanggung jawab yang besar untuk membangun opini masyarakat secara obyektif mengenai wacana green design. Ada tiga peran penting media dalam wacana green design, media sebagai sarana kampanye pengenalan tentang green design, media sebagai sarana edukasi masyarakat tentang green design dan media sebagai saran promosi dari produk-produk green design. 


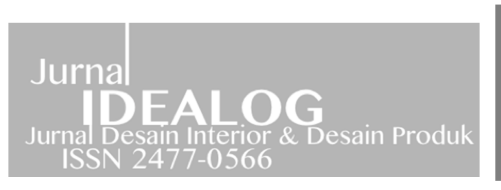

Jurnal I DEA L O G

Jurnal Desain Interior \& Desain Produk

Vol.1 No.1, April 2016

ISSN 2477 - 0566

\subsection{Media sebagai sarana kampanye Green design}

Dalam peranya sebagai sarana kampanye media berfungsi untuk meningkatkan kesadaran, menginformasikan, atau merubah perilaku target kampanye. Menurut Rogers dan Storey (1987) kampanye adalah serangkaian kegiatan atau tindakan komunikasi yang sudah terencana dengan mempunyai tujuan untuk menciptakan efek tertentu pada sejumlah besar khalayak yang dilakukan secara berkelanjutan pada kurun waktu tertentu. Ada 4 ciri dasar dari komunikasi kampanye yaitu, yaitu sumber yang jelas, ada yang menjadi penggagas, perancang, penyampai sekaligus penanggung jawab suatu produk kampanye (pembuat kampanye). Kegiatan kampanye dilandasi oleh prinsip persuasi, yaitu mengajak dan mendorong massa untuk bisa menerima atau melakukan sesuatu yang dianjurkan atas dasar kesukarelaan dan kesadaran.

Media, dalam hal ini media cetak atau eletronik merupakan sarana persuasi yang efektif dan efisien karena bisa menjangkau banyak masyarakat dengan waktu yang cepat. Dalam kampanye green design, media berperan untuk memberi kesadaran dan memberi informasi mengenai green design sebagai alternatif jawaban solusi dari masalah lingkungan kepada masyarakat. Dalam peranya sebagai kampanye green design, maka yang perlu ada dalam media adalah ajakan kepada masyarakat untuk ikut berperatisipasi memujudkan gerakan green design dalam kehidupan sehari. Dengan memberikan pengetahuna bahwa dengan melakukan perwujudan gerakan green design dalam bentuk sekecil apapun akan memberikan dampak positif bagi lingkungan disekitarnya. Keberhasilan perwujudan gerakan ini merupakan bentuk partisipasi masyarakat dalam menjaga keberlangsungan hidup secara baik dan benar.

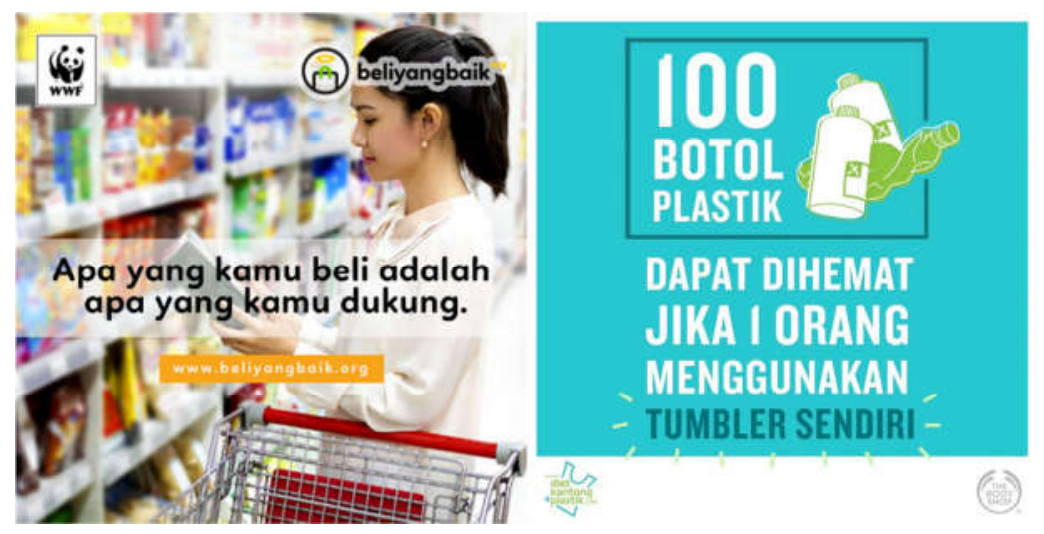

Gambar 1. Contoh media sebagai sarana kampanye gerakan green design (sumber: WWF Indonesia dan The Body Shop Indonesia)

Salah satu bentuk media yang paling mudah untuk dibuat dan diakses oleh masyarakat adalah media cetak, sebagaian besar dalam bentuk poster. Seperti gambar contoh diatas, kampanye yang dilakukakan oleh WWF Indonesia dan Kampanye oleh The Body Shop Indonesia dalam bentuk media poster. Kampanye green design yang dilakukan oleh WWF Indonesia dan The Body Shop Indonesia bersifat persuasif dengan cara positif, isi ajakan berupa himbauan menegani gerakan green design dan alasan serta manfaat yang akan 
diperoleh masyarakat. Dengan bentuk ajakan positif tanpa ada paksaan akan lebih mudah diterima dan masyarakat tidak merasa dipaksa untuk melakukan partispasi menerapkan wacana green design. Karena pada dasarnya penerapan wacana green design harus melalui kesadaran diri masing masing dan mengetahui manfaat yang akan dirasakan terhadap lingkungan sekitarnya.

Melalui berbagai bentuk media sebagai sarana kampanye, ajakan tidak hanya datang dari satu arah saja, namun masyarkat juga diajak saling memberi ajakan dan berkomunikasi mengenai green design. Media elektronik khusunya internet yang di dalamnya terdapat media komunikasi sosial, meupakan media yang efektif dan paling banyak digunakan sebagai sarana kampanye green design yang melibatkan masyarakat yang tergabung di dalamnya. Perkembangan pola pikir terhadap media juga menciptakan bentuk media baru yang lebih interaktif, mengunakan media instalasi yang ditempatkan di tempat umum. Tidak hanya sekedar sebagai media kampanye saja namun juga sebagai desain media yang kreatif dan menarik masyarakat. Bentuk media kampanye apapun pada akhirnya tujuan utamanya adalah tercapainya penerapan wacana green design oleh masyarakat sebagai alternatif solusi permasalahan lingkungan global yang sedang terjadi saat ini.

\subsection{Media sebagai sarana edukasi green design}

Tujuan komunikasi adalah tercapainya suatu pemahaman bersama (mutual understanding ) antara dua atau lebih partisipan komunikasi terhadap suatu pesan ( dalam hal ini adalah ide baru ) melalui saluran komunikasi tertentu. Rogers dan Floyed Shoemaker (1987) menegaskan bahwa " difusi merupakan tipe komunikasi khusus, yaitu mengkomunikasikan inovasi. Ini berarti kajian difusi merupakan kajian komunikasi yang berkaitan dengan gagasan - gagasan baru, sedangkan pengkajianya meliputi semua bentuk pesan". Teori difusi ini sangat penting jika dihubungkan dengan kemampuan media dan opinion leader untuk menciptakan edukasi pengetahuan, ide dan penemuan baru serta membujuk sasaran untuk mengadopsi inovasi tersebut.

Edukasi sendiri memiliki pengertian yaitu pembelajaran pengetahuan, keterampilan, dan kebiasaan sekelompok orang yang diturunkan dari satu generasi ke generasi berikutnya melalui pengajaran, pelatihan, atau penelitian (Dewey,1944). David Popenoe mengemukakan bahwa ada empat macam fungsi pendidikan yakni sebagai berikut:

1. Transmisi (pemindahan) kebudayaan.

2. Memilih dan mengajarkan peranan sosial.

3. Menjamin integrasi sosial.

4. Sekolah mengajarkan corak kepribadian.

5. Sumber inovasi sosial.

Berdasar dari teori diatas maka peran media dalam wacana green design sebagai sarana edukasi masyarakat sangat penting. Lewat media wawasan mengenai wacana green design disampaikan kepada masyarakat untuk menciptakan dan memberi pengetahuan yang 


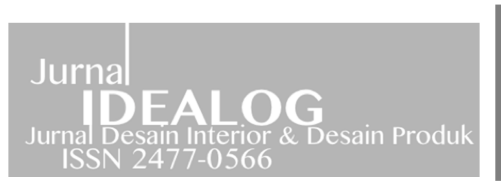

Jurnal IDEA LOG

Jurnal Desain Interior \& Desain Produk

Vol.1 No.1, April 2016

ISSN 2477 - 0566

baru. Melalui media wacana green design dinformasikan secara komunikatif kepada masyarakat luas. Isi informasi bukan hanya sekedar pemberitahuan mengenai wacana green design namun juga pengetahuan apa yang dimaksud dengan green design. Dalam memberikan pengetahuan mengenai wacana green design sebaikanya disajikan dengan bahasa yang mudah dimengerti dan disertai data-data pendukungnya. Selain data pendukung juga perlu dijelaskan mengenai sebab dan akibat dari keruskan lingkungan dan bagimana solusi yang ditawarkan oleh konsep green design. Solusi yang ditwarkan sebaiknya menggunakan contoh yang sederhana yang diterapkan disekitar lingkungan masyarakat. Dengan memberikan pengetahuan yang baru diharapkan masyarakat tidak hanya tahu tapi juga mengerti dan kemudian menerapkan konsep tersebut.
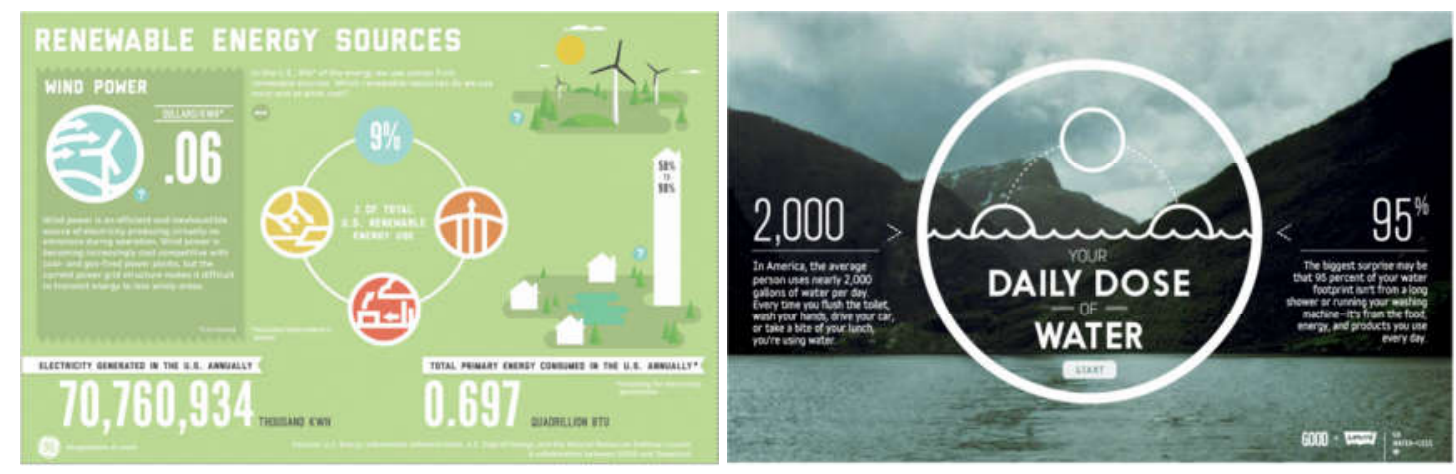

Gambar 2. Contoh media sebagai sarana kampanye gerakan green design (sumber: General Electric dan Levis)

Pada gambar contoh sarana edukasi green design di atas dapat dilihat bagaimana GE (General Electric) memberikan informasi yang edukatif menegenai sumber energi yang terbarukan sebagai alternatif solusi permasalahan krisis sumber energi saat ini yang sebagian besar sumbernya dari energi tak terbarukan. Penyajian menggunakan data-data yang dikemas dalam bentuk infografis bertujuan meneyerdahanakan data agar mudah dimengerti oleh masyarakat luas, selain itu penyajian infografis akan lebih menarik daripada data dalam bentuk tulisan atau angka saja. Levis juga melakukan hal yang sama, dengan grafis yang menarik dan penyajian data yang sederhana memberikan pengetahuan mengenai penggunaan air setiap harinya, dengan tujuan untuk memberi pengetahuan kepada masyarakat bagaimana kita seharusnya menggunakan air sesuai dengan kebutuhan dan digunakan sebijak mungkin sesuai dengan Bentuk-bentuk media sebagai sarana edukasi bisa berbagai macam sesuai dengan perkembangan teknologi dan budaya massa saat ini. Mulai dari penggunaan media cetak hingga media interaktif yang muktahir. Media yang efektif dan populer saat ini adalah melalui komunitas-komunitas sosial yang menginkutsertakan masyarakat secara langsung ikut terlibat dalam proses edukasi wacana green design. Efektifitas media komunitas adalah proses edukasi disertai juga dengan praktek sehingga masyarakat yang menjadi sasaran edukasi tidak hanya mengerti secara pola pikirnya saja namun juga dalam tindakanya. 


\subsection{Media sebagai sarana promosi produk Green design}

Beberapa pendapat dari para ahli pemasaran dan praktisi tentang promosi, yaitu sebagai berikut. Pengertian promosi menurut Saladin dan Oesman ( 2002 ) adalah suatu komunikasi informasi penjual dan pembeli yang bertujuan untuk merubah sikap dan tingkah laku pembeli, yang sebelumnya tidak mengenal menjadi mengenal sehingga menjadi pembeli dan mengingat produk tersebu. Kemudian menurut Alma ( 2006 ) adalah promosi adalah sejenis komunikasi yang memberi penjelasan dan meyakinkan calon konsumen mengenai barang dan jasa dengan tujuan untuk memperoleh perhatian, mendidik, mengingatkan dan meyakinkan calon konsumen.

Menurut Kotler ( 2005:249 ) mengenai bauran komunikasi pasar adalah penggabungan dari lima model komunikasi pemasaran, yaitu iklan, promosi penjualan, hubungan masayarakat dan pemberitaan, penjualan pribadi dan pemasaran langsung dan interaktif. Bauran komunikasi pemasaran tersebut selalu dikaitkan dengan penyampaian sejumlah pesan dan penggunaan visual yang tepat sebagai syarat utama keberhasilan dari sebuah program promosi. Disini peran media sangat penting dalam menyampaikan promosi sebuah produk. Bentuk media sebagai sarana promosi adalah iklan. Iklan merupakan bagian dari pemasaran sauatu produk ( Tinarbuko, $2007: 1$ ). Periklanan menurut Kotler ( $2005: 277$ ) didefinisikan sebagai segala bentuk penyajian non - personal dan promosi ide, barang, atau jasa oleh suatu sponsor tertentu yang memerlukan pembayaran. Dan iklan adalan salah satu bentuk media hasil komunikasi massa.
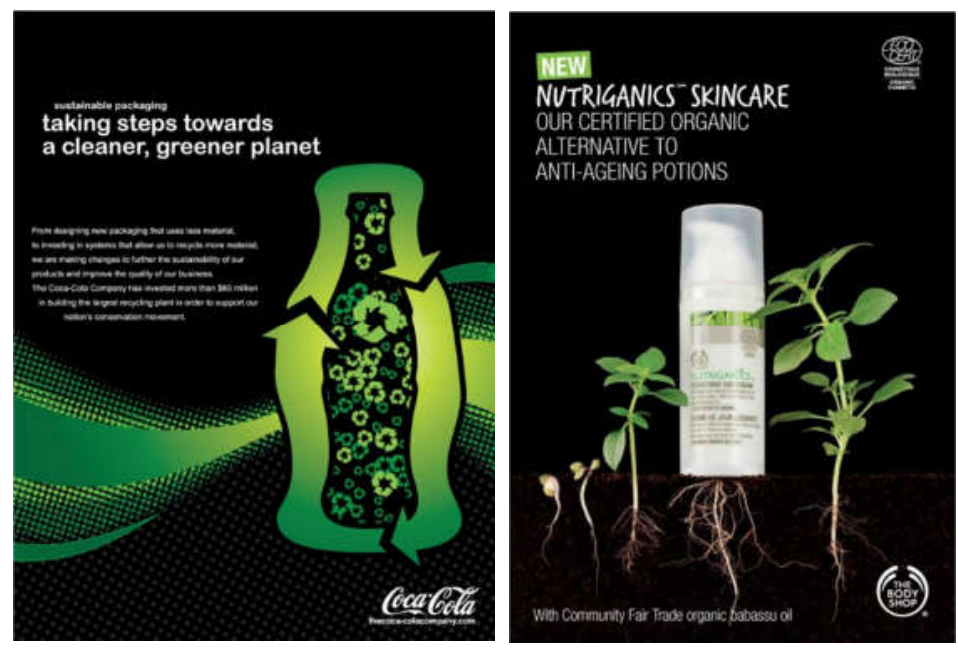

Gambar 5. Contoh media sebagai sarana Promosi produk green design (sumber: CocaCola dan The Body Shop Indonesia)

Pada gambar contoh diatas, CocaCola melakukan promosi mengenai produknya yang menerapkan konsep green design. CocaCola menjelaskan kepada masyarakat mengenai penggunaan kemasan yang ramah lingkungan, sehingga konsumen yang membeli produk tersebut secara tidak langsung ikut berpartispasi dalam menyelamatkan lingkungan sesuai 
dengan konsep green design. Sedangkan The Body Shop menjelaskan pada masyarakat mengenai produknya yang menggunakan bahan organik, sehingga masyarakat yang menggunakan akan merasa aman. Konsep green design yang dibawa oleh The Body Shop lebih ditujukan pada keamanan bahan-bahan produknya dan kesehatan konsumen yang menngunakan produknya. Secara umum kedua perusahaan tersebut melakukan promosi produk-produknya yang berkonsep green design dengan tujuan meyakinkan masyarakat yang menggunakan produknya merasa aman dan ikut berapartisipasi dalam meneyelamatkan lingkungan sekitar.

Menurut Kotler (2005:278) upaya periklanan mempunyai beberapa tujuan antara lain: menginformasikan adanya merk produk di pasaran, membujuk konsumen untuk membeli produk, dan mengingatkan konsumen terhadap produk. Dalam peranya sebagai media promosi produk green design, media dalam bentuk iklan berfungsi dan memepunyai tujuan untuk memberi informasi, membujuk konsumen untuk membeli dan selalu ingat akan produk yang di promosikan. Sebagai media promosi media memberi informasi mengenai produk yang di promosikan sebagai produk green design, sehingga masyarakat akan mengetahui dan yakin bahwaproduk tersebut memang produk green design. Setelah memberikan informasi mengenai produknya tugas selanjutnya adalah membujuk konsumen untuk mau membeli atau menggunakan produk yang di promosikan sebagai tindakan nyata pola pikir green design yang ramah lingkungan. Ketika konsumen sudah membeli dan menggunakan maka proses selanjutnya bagaimana konsumen akan selalu ingat akan prdoduknya dengan memberikan persuasi bahwa bila menggunakan produk yang green design tersebut secara berkelanjutan maka konsumen juga berperan aktif dalam menjaga lingkungan. Walaupun tujuan utama dari media iklan adalah tetap pada tetap pada target penjual suatu produk.

\section{Kesimpulan}

Berdasarkan kajian pada penelitian ini bahwa wacana tentang green design sebagai jawaban akan isu kerusakan lingkungan perlu di informasikan secara jelas kepada msayarakat. Proses penginformasian tersebut membutuhkan sebuah peran media yang merupakan bagian dari sarana komunikasi kepada masyarakat. Berikut kesimpulan yang dihasilkan:

a. Peran media sebagai sarana kampanye green design adalah untuk meningkatkan kesadaran, menginformasikan, atau merubah perilaku masyarakat menuju wacana green design.

b. Peran media berikutnya sebagai sarana edukasi mengenai green design. Tujuanya adalah memberi pengetahuan baru, kemudian mempersuasi pola pikir dan tindakan masyarakat menuju wacana green design yang ramah lingkungan.

c. Selanjutanya media digunakan oleh produsen sebagai saran promosi produk green design melalui iklan. Tujuan utama dari iklan adalah membujuk masyarakat sebagai target konsumen untuk menyakini bahwa produk yang dipromosikan adalah produk green design yang kemudian membujuk kosumen sebagai target pasarnya mau menggunakan produknya tersebut. 
d. Bentuk media berkembang sesaui dengan kemajuan teknologi, tidak hanya bersifat satu arah namun juga dua arah secara iteraktif

e. Kampanye yang dilakukan dengan ajakan yang positif dan tidak memaksa akan lebih mudah diterima oleh masyarakat

f. Keberhasilan kampanye mengenai wacana green design akan berpengaruh lansung pada keberhasilan penerapan wacana tersebut

g. Penyajian data infografis secara sederhana banyak digunakan oleh perusahaan atau lembaga untuk menerangkan data dan fakta mengenai wacana green design agar mudah dibaca dan dipahami oleh masyarakat

Sebagai penutup, peran media tidak dapat dilepas dari wacana green design. Dimulai dari proses penginformasian dan pengenalan, edukasi pengatahuan hingga pada ahirnya masyarakat mau merubah pola pikir, tindakan dan menggunakan produk-produk yang sesuai dengan wacana green design.

\section{Daftar Pustaka}

[1] Buchari Alma, (2006). Pemasaran dan Pemasaran Jasa, Alfabeta, Bandung.

[2] Conggres of United States Office of Technology Assessment, (1992)

[3] Dewey, John (1966). Democracy and Education. The Free Press, University of Michigan

[4] Engangge By Design. Sustainable design Research, diakses dari http://engagebydesign.org/values/ pada tanggal 12 Juni 2015 pada pukul 17.00.

[5] Fidler, Roger, (1997). Mediamorfosis: Understanding New Media, Thousand Oaks, California: Pine Forge Perss.

[6] Kotler, Philip. Marketing Management.

[7] McLennan, J. F. (2004), The Philosophy of Sustainable Design, Ecotone Publishing, Kansas

[8] Mulyana, Deddy. Ilmu Komunikasi Suatu Pengantar. PT. Remaja Rosdakarya, Bandung

[9] Peran dan Fungsi Media dalam Membangun Opini Publik, 17 Maret 2009 diakses dari www.blogdetik.com pada tanggal 12 Juni 2015 pada pukul 17.00

[10] Popenoe, David. (1999) Critical Review Guide Sociology. Pearson

[11] Riyanto, Theophilus J. Kekuatan Media Massadalam Kampany Kepresidenan di Amerika Serikat. Dosen Jurusan Sastra Inggris, Universitas Kristen Petra, Surabaya

[12] Rogers, Everett M. dan F. Floyd Shoemaker. Communication of Innovations. Terjemahan Abdillah Hanafi Memasyarakatkan Ide-Ide Baru. Usaha Nasional. Surabaya.

[13] Rogers, E. M., \& Storey J. D. (1987). Communication Campaign. Dalam C. R. Berger \& S.H. Chaffe (Eds.), Handbook of Communication Science. New Burry Park, CA:Sage.

[14] Saladin, Djaslim dan Oesman, Yevis Marty. 2002. Perilaku Konsumen dan Pemasaran Strategik. Jakarta: Balai Pustaka

[15] Tinarbuko, Sumbo. Semiotika Komunikasi Visual. Jalasutra. Yogyakarta 


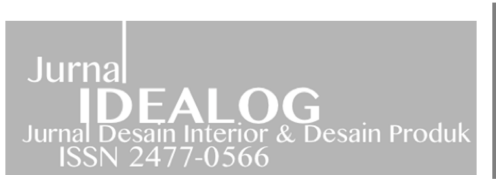

Jurnal I D E A L O G

Jurnal Desain Interior \& Desain Produk

Vol.1 No.1, April 2016

ISSN 2477 - 0566

[16] www.eone.wordpress.com ( Kekuatan Media Massa, 2 April 2010 )

[17] www.ruangdosen.wordpress.com ( Kontribusi Teori - Teori Komunikasi Dalam Komunikasi Inovasi, 10 September 2008 )

[18] www.thinkgreen.com diakses pada tanggal 10 Juli 2015 pada pukul 19.00 